\title{
Los consejos "A latere principis u de su theniente general" en el País Bajo de los Austrias, 1577/78-1609. Una presentación
}

The Councils "A latere principis u de su theniente general" in the Habsburgs Netherlands,

\author{
1577/78-1609. An Introduction
}

\section{Hugo de Schepper}

Profesor Emérito de la Universiteit Nijmegen

\begin{abstract}
Resumen: Esta contribución constituye una presentación de un nuevo estudio sobre las élites de poder y la historia legal y política de los Consejos de gobierno en Flandes, que abarca desde la Reconciliación de las provincias valonas con Felipe II (1579) hasta la Tregua de los Doce Años (1609). En la primera parte, se trata sobre las estructuras internas de los tres Consejos, así como - sobre la base de unas cien biografías - el modelo de personajes que sirvieron en su marco. La segunda parte estudia sus competencias jurídicas y reales en un estado de derecho no escrito, donde el monarca era la fuente de todo derecho nuevo que no conocía la trias politica. Asimismo, se investiga sobre los procedimientos de toma de decisiones o asesores en el marco de cada Consejo. De este modo, y siguiendo un estudio cronológico, se dibuja la toma de posiciones de los Consejos en una coyuntura de guerra civil y también sus participaciones e influencia en los procesos decisionales de política interior y exterior.
\end{abstract}

Palabras clave: Consejos Colaterales; Flandes; Jurisdicción

Abstract: The aim of this contribution is to present a new approach to the study of the elites of power, and the legal and political history of the Collateral Council in Flanders, which embrace from the Reconciliation of the wallonian provinces with Philip II (1579) until the Twelve Years' Truce (1609). At the first part, the internal structures of the three Collateral Councils are treated, as well as - with the base of circa 100 biographies - the kind of people that served on them. The second part studies the jurisdictional and real competences of these Councils, in the framework of a non-written rule of law, where the King was the source of every new law that did not know the trias politica. Even, the procedures of decission making at the framework of every Council are studied. Thanks to this, and following a chronological

(C) 2018 Philostrato. Revista de Historia y Arte 
order, the different positions that the Councils defended, in a conjuncture of civil war, are described, as well as their influence at the decission making in questions related with internal and external affairs.

Keywords: Collateral Councils; Flanders; Jurisdiction

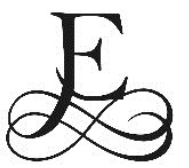

I presente artículo constituye una presentación de la puesta al día que me encuentro realizando en la actualidad sobre el trabajo que llevé a cabo para la elaboración y actualización de mi tesis doctoral del año 1972 relacionada con los Consejos llamados más tarde 'Colaterales', y que será publicada a lo largo de 2018 como colofón a mi carrera de más de 60 años estudiando las instituciones del País Bajo ${ }^{1}$. De este modo, creo que puede servir como un avance de los estudios sobre las instituciones llevados a cabo durante las últimas décadas.

En dicha publicación, un capítulo preliminar trata sobre la complicada transición que se produjo desde la Pacificación de Gante a finales de 1576 acto de rebelión casi general del País Bajo contra el régimen confesional y político de Felipe II-, hasta la restauración de la legalidad en las provincias de Hainaut, Valenciennes, Artois y Lille-Douai-Orchies a comienzos de 1579. En el curso de 1578, estas provincias denominadas valonas, en las cuáles el clero y la nobleza dominaban tradicionalmente, se habían distanciado del gobierno "democrático" de los Estados Generales rebeldes y asimismo de la persecución anticatólica en las ciudades de las provincias más protestantes: Brabante, Holanda, Flandes y Zelanda. Aprovechándose de esta tendencia separatista, el Teniente General Alejandro Farnesio, príncipe de Parma y sucesor de don Juan de Austria, consiguió concluir el Tratado de Arrás (17 de mayo de 1579). Al aceptar el catolicismo romano como única religión y a Felipe II como Soberano de los Países Bajos, los Estados valones se reconciliaron con Felipe II bajo determinadas condiciones, entre otras: la salida de todos los extranjeros, tanto del ejercito como del aparato político y administrativo; el perdón general respecto al pasado; y un Consejo de Estado que estuviera compuesto por nobles o "consejeros de ropa corta", y que gobernara como cuerpo de pares con el Teniente General del Soberano, aunque esta propuesta se rechazó en la última versión del Tratado. Finalmente, el Tratado de Arrás restauró las relaciones entre los Consejos y el Soberano y el Gobernador General "como bajo Carlos V". Por lo tanto, todas las decisiones tenían que llevar la firma de un consejero responsable; de este modo, para los Estados sería una garantía de que se había establecido la toma de decisiones de manera regular en los Consejos mediante "naturales del país" y no en "extranjeros" u otro tipo de redes informales. Sin embargo, muchos artículos del Tratado nunca fueron aplicados, ya que las principales

\footnotetext{
* Hugo de Schepper, De Regeringsraden naast Landsheren en Landvoogden in het Habsburgse Nederland. Leden, Instellingen en Algemene Politiek, 1577/1580-1609 (a publicar por la Koninklijke Academie voor Wetenschappen, Letteren en Schone Kunsten van België).

${ }^{1}$ Con excepción de la provincia de Luxemburgo y de la provincia valona de Namur.
} 
provincias no se adhirieron al mismo y Brabante, Holanda, Flandes y Zelanda continuaron la lucha en el marco de la Unión de Utrecht.

\section{Organización interna y composición de los Consejos}

A continuación, la primera parte del libro trata sobre los diferentes oficios que existían dentro de los Consejos - de Estado, Secreto o Privado y de Finanzas- al lado de los Lugartenientes de Felipe II como Soberano de los Países Bajos hasta 1598 y después al lado de los Archiduques "independientes" Alberto e Isabel. Cada Consejo tenía diversos oficios con atribuciones específicas para cumplir tareas propias en el marco del colectivo. De este modo, los oficios se estudian en combinación con las biografías de las personas que los ocuparon, hasta un total de más de cien -de extensión variable, según la importancia del personaje- con los currículos de los consejeros, secretarios y otro personal de servicio, sus orígenes sociales y familiares, eventualmente sus ideas, personalidad, ...

En el Tratado de Arrás se había acordado conceder a los Estados valones un cierto derecho de participación -y hasta de veto- en el proceso de nombramiento de los consejeros. De este modo, de los doce consejeros de Estado, ocho deberían haber sido necesariamente ex rebeldes y, además ningún extranjero tendría acceso a los Consejos de gobierno. Esta disposición no solamente se oponía a un eventual regreso de hispanos, sino también de borgoñones, porque se les consideraba "no naturales del país". Así, muchos y relevantes personajes fieles al monarca se quedaron sin posibilidad de ser integrados en el sistema.

Esta integración de ex rebeldes en los Consejos no siempre fue fácil, como nos demuestra el caso de Charles-Philippe de Croÿ, marqués de Havré y medio hermano del renombrado duque de Aerschot. Pese a que desde 1585 retornó a la obediencia al monarca, hasta 1588 no se le permitió volver a ocupar su sede en el Consejo de Estado. Sin embargo, su servicio se fue consolidando después y llegó a ser jefe de Finanzas en 1599, e incluso estuvo implicado en negociaciones directas con los rebeldes, cuando en 1595 entró en contacto de modo informal con un antiguo empleado suyo, que había entrado en el servicio del estatúder Mauricio de Nasau. Mediante esta iniciativa, satisfizo los deseos prioritarios que los Consejos expresaban en cada ocasión que podían; a saber, negociar la reunificación de los Países Bajos sin que interviniese el rey español. De la prioridad para la pacificación de todo el país -o sea por negociaciones o sea por las armas- se derivaba la oposición de todos los consejeros, en mayor o menor medida, contra la nueva orientación internacional de Felipe II desde finales de los años ochenta, destinada a ayudar a la Liga Católica en Francia contra el pretendiente al trono, el protestante Enrique de Béarn, por miedo a que la "reconquista" de las provincias rebeldes sufriera un parón. 
Hay que recordar que, en virtud del tratado de reconciliación con las provincias valonas, durante el gobierno de Farnesio casi la mitad de los miembros de los tres Consejos había participado en la rebelión flamenca. Entre ellos, a pesar de su naturaleza borgoñona, el astuto ex rebelde Jean Richardot, que llegó a ser pocos años después el ministro de mayor confianza de Farnesio. De hecho, llegaría a ocupar la presidencia del Consejo de Estado, la cual alternaría hasta el periodo de los Archiduques con el jurista Christophe d'Assonleville, procedente de Artois, a la que uniría en 1597 la presidencia del Consejo Privado. Su papel político fue fundamental en las negociaciones con los rebeldes, aunque su nepotismo le produjo numerosos quebraderos de cabeza².

El papel de Richardot fue aún más importante, debido a las numerosas vacantes que se produjeron en el Consejo de Estado. Por ejemplo, al morir el duque de Parma a finales de 1592, el Consejo contaba con tan sólo seis miembros que siempre habían sido fieles al propio monarca, de los cuales tres o cuatro pertenecían a la alta nobleza y dos o tres eran juristas burgueses. Tras Farnesio, el siguiente Gobernador Pedro Ernesto, conde de Mansfeld, procuró completar el Consejo invitando a las reuniones a personas sin nombramiento según la naturaleza de la materia a tratar. No sería hasta 1595, durante el periodo de su sucesor, el archiduque Ernesto de Austria, cuando tres nuevos miembros entraron en el Consejo de Estado, como fueron el obispo de Amberes, que falleció poco después, Philippe de Croÿ-Solre y Juan Bautista de Tassis, el primer hispano quince años después del Tratado de Arrás.

Philippe de Croÿ, baron de Molembais y conde de Solre, era un noble irreprochable en su fidelidad a Felipe II y a los Archiduques. De hecho, desde 1591 hasta 1595 había servido con intervalos en la corte hispana como capitán de la Guarda de Archeros de Corps. Su figura es muy interesante, pues fue uno de los pocos consejeros de espada que ponía por escrito sus observaciones, que eran a la vez constructivas y críticas. Por ejemplo, sugería que para ganar al pueblo flamenco que sufría tanto por los motines del ejército, era indispensable financiar un ejército de "naturales". Aunque no se le pudiese acusar de hispanofobia, era partidario de un ejército sin españoles, lo que -a su parecer- facilitaría la reunificación pacífica con las regiones sublevadas ${ }^{3}$. De hecho, tras la Tregua en 1609, y cuando era evidente que el matrimonio

\footnotetext{
2 Art. Assonlleville, Christoffel d', heer van Haulteville (Atrecht, ca 1528-Brussel, 10 april 1607), en: Antoon Van Der Lem (ed.), 'De Bello Belgico'. De Tachtigjarige Oorlog of de Opstand in de Nederlanden (http://dutchrevolt.leidenuniv.nl/personen/a/assonleville.htm), 5 p.; art. "Richardot", en: Nationaal Biografisch Woordenboek (Bruselas: Academiën, 1964), I, pp. 762775.

3 Bernardo José García García, "'Ganar los corazones y obligar los vecinos'. Estrategias de pacificación de los Países Bajos, 1604 - 1610", en España y las 17 Provincias de los Países Bajos. Una revisión historiográfica, siglos XVI-XVIII, Ana Crespo Solana y Manuel Herrero Sánchez (eds.), (Córdoba: Universidad, 2002), I, pp. 149-150; Eduardo de Mesa Gallego, La pacificación de Flandes. Spínola y las campañas de Frisia, 1604-1609 (Madrid: Ministerio de Defensa, 2009), pp. 35-56.
} 
archiducal no podía tener hijos, fue un defensor convencido de la incorporación de los Países Bajos a la Monarquía Hispana4.

En lo que se refiere a Tassis, no encontró reacciones negativas a su nombramiento por el hecho de su naturaleza española ${ }^{5}$. Lo mismo sucedería cuando al año siguiente se nombró a otro hispano, Francisco de Mendoza, almirante de Aragón. Mendoza no sólo fue nombrado consejero de Estado, sino también mayordomo mayor de la corte archiducal y maestre de campo, destinado por tanto a ser uno de los consejeros más influyentes del archiduque Alberto. Sin embargo, en 1600 en la batalla de las dunas de Nieuwpoort, cayó vergonzosamente en manos rebeldes. Mauricio de Nasau le otorgó una elegante residencia cerca de La Haya como prisión, e incluso le dejó posar ante su pintor de corte Van den Queeckborne, un refugiado de Amberes. El espléndido resultado se encuentra en el Rijksmuseum de Ámsterdam. Después de su puesta en libertad, se encontró con su caída en desgracia tanto en Bruselas como en Valladolid, porque esa cercanía al Estatúder demostraba que se había prestado a negociaciones con rebeldes y protestantes sin concertarse con los Archiduques, ni tampoco con Felipe III o con sus representantes en Bruselas ${ }^{6}$.

Mientras, los Archiduques se esforzaban por restablecer las relaciones con los "naturales", y una de sus principales herramientas fue el nombramiento de consejeros, así como la concesión de mercedes y ayudas de costa, ayudados por Felipe III. De este modo, el Consejo de Estado alcanzó otra vez su composición máxima mediante el nombramiento, sobre todo, de nobles de espada, frenando la tendencia hacia una preponderancia de la nobleza togada. Entre los nuevos consejeros de Estado encontramos, por ejemplo, al hijo mayor de Guillermo de Orange, de nombre Felipe Guillermo, que había permanecido cerca de treinta años en España como rehén de Felipe II ${ }^{7}$; así como al ex rebelde y ex calvinista Charles de Croÿ, príncipe de Chimay e hijo del duque de Aerschot, lo que nos da una clara imagen de la idea de reconciliación.

\footnotetext{
${ }^{4}$ Alicia Esteban Estríngana, "Las provincias de Flandes y la Monarquía de España. Instrumentos y fines de la política regia en el contexto de la restitución de soberanía de 1621", en La Monarquía de las Naciones. Patria, nación y naturaleza en la Monarquía de España, Antonio Álvarez-Ossorio Alvariño y Bernardo José García García (eds.), (Madrid: Fundación Carlos de Amberes, 2004), pp. 215-245; Id., "Flemish elites under Philip III's patronage, 1598-1621: household, court and territory in the Spanish Habsburg Monarchy", en A Constellations of Courts. The Courts and Households of Habsburg Europe, 1555-1665, René Vermeir, Dries Raeymaekers y José Eloy Hortal Muños (eds.), (Lovaina: Leuven University Press, 2014), pp. 123-166 (espec. 127).

5 Alicia Esteban Estríngana, "De capitanías generales y tesorerías militares: el control financiero y sus dilemas en tiempos de Alejandro Farnesio, siglo XVI", Estudis. Revista de Historia Moderna, XLI, 2015, pp. 9-42.

6 Werner Thomas, "The "Spanish Faction" at the court of the archdukes Albert and Isabella", en: Vermeir et al. A Constellation of Courts, pp. 167- 221 (espec. 176-178, 200).

7 Adela Repetto Álvarez, "Felipe II y el hijo del Príncipe de Orange", Boletín de la real Academia de la Historia, t. 162, (1968), pp. 63-95.
} 
Los nombramientos de miembros de ropa corta en el Consejo de Estado hay que explicarlos no tanto como el resultado de una búsqueda de capacidades asesoras sobre ciertas materias, si no como una forma de canalizar la gracia real, instrumento básico para la gobernación. Estos nobles pertenecían a viejos linajes, y tenían prestigio y dignidad en la sociedad. En su mayoría, sus tierras estaban localizadas en los Estados de provincias rurales como Hainaut y Artois, donde residían en sus castillos y grandes señoríos. Su cursum honorum solía contemplar una carrera como comandantes y victorias militares, combinadas con el ejercicio del gobierno de alguna provincia. Del mismo modo, algunos fueron nombrados chefs (jefes) en el Consejo de Finanzas, y a otros se les destinó a misiones diplomáticas. Sin embargo, eran oficios y nombramientos con poca carga política, por lo que, a largo plazo, la nobleza estaba perdiendo su influencia a favor de togados capaces y tecnócratas más dóciles.

Uno de los ámbitos que fueron ocupando estos consejeros juristas de Estado, fue el Consejo Secreto o Privado. Este Consejo constituía un núcleo permanente de gobernación y justicia, y contaba con un jefe-presidente, uno o dos fiscales, seis "maestros de peticiones" y además una extensa audiencia y secretaría. Su relevancia ceremonial era menor que la de los consejeros de ropa corta, pero en realidad llevaban la marcha diaria del aparato gubernamental a disposición del Soberano. La carrera típica de estos juristas, comenzaba normalmente a través de su estudio en la Universidad, donde se licenciaban o doctoraban en derecho romano o canónico. Posteriormente, comenzaban a ejercer como síndicos de una ciudad o como abogados en un Consejo provincial, para pasar posteriormente al Gran Consejo de Malinas y, finalmente, al Consejo Privado. Desde allí, algunos culminarían su carrera mediante la obtención de la presidencia de uno u otro Consejo de Justicia, el oficio de Consejero de Estado o la jefatura-presidencia del propio Consejo Privado. Es el caso de algunos personajes como Guillermo de Pamele y Juan van der Burch.

Mientras, el tercer Consejo en la jerarquía, el de Finanzas, conocía una dualidad socio-jurídica análoga a la del Consejo de Estado. Los dos o tres chefs solían pertenecer a la nobleza, y se alternaban en el ejercicio del puesto para permitir a uno de ellos ocupaciones fuera de la Corte, así como para asistir a las reuniones del Consejo de Estado del que solían ser miembros. El Consejo de Finanzas era principalmente una oficina técnica, cuya adaptación a la burocratización que se llevaba a cabo en la Corte de Bruselas nivelaba la prioridad de los jefes nobles. En general, como militares sabían manejar la espada mejor que la pluma y, tal y cómo lo describía Farnesio, "No podían llevar el trabajo de visitar tantos papeles". Por lo tanto, el papel técnico recaía con mayor fuerza en el tesorero y los comisarios de Finanzas, que eran entre tres y nueve. Los poseedores de ambos oficios habían seguido una carrera en el comercio, en el mundo de las finanzas, como auditores en las Cámaras de 
Cuentas, o incluso como recaudadores en la administración de los dominios de la Corona.

La pérdida del papel que ejercían los jefes nobles en el Consejo, llevó al archiduque Alberto a confirmar esta evolución por reglamento, indicando que el tesorero general tuviera la dirección y gestión del Consejo de Finanzas. De este modo, Johan van Drenkwaert, perteneciente a una familia de empleados públicos de Dordrecht, y por tanto el último holandés en el gobierno flamenco de los Austrias, elevó las responsabilidades que ya tenía como tesorero general, cargo que ejercería desde 1588 hasta 1606. Al tesorero general le incumbiría la difícil misión de tener al Consejo de Finanzas y al príncipe permanentemente al tanto de los saldos disponibles de los ingresos inmuebles del Soberano y de los rendimientos de los donativos de los Estados, así como sobre la posibilidad de pagar la Corte, las tropas del país, las fortificaciones, los salarios de los consejeros de gobierno, del Gran Consejo de Malinas, ...

En los tres Consejos, el nombramiento de los consejeros fue la prerrogativa del Soberano previa propuesta del Lugarteniente. Excepcionalmente, Felipe II nombró a consejeros fuera de la lista, ya que los diversos Gobernadores, en su correspondencia secreta con el Soberano, hacían proposiciones que diferían de las aportaciones oficiales ${ }^{8}$. La mayoría de los nombramientos se concedían por la vida del Soberano o por un periodo determinado ("tant qu'il nous plaira"). ${ }^{9}$ Sin embargo, con excepción de los consejeros de Estado y de los jefes del Consejo Secreto y de Finanzas, fue el Gobernador General mismo quien designaba a los consejeros sin concertar con Felipe II. En especial, esto fue así después de la Cesión a los Archiduques en 1598, ya que Felipe III les dejó libertad para componer los Consejos. Sin embargo, en 1606 hubo una tentativa velada para remover a Richardot, el ministro flamenco con mayor influencia en el gobierno ${ }^{10}$.

Entre las razones que influyeron a los Gobernadores para nombrar a consejeros, encontramos principalmente tradiciones familiares $y$ recomendaciones. Así, en el grupo de consejeros de ropa corta encontramos a los viejos linajes típicos, mientras en los oficios técnicos se nota algo menos ese nepotismo, aunque sí es muy reconocible en las secretarías de los Consejos Privado y de Finanzas. Tras su ingreso en el puesto, los consejeros se convertían en "domestici regis" en la Corte y gozaban de salarios,

\footnotetext{
8 Hugo de Schepper, "El nombramiento de altos magistrados y funcionarios para los Países Bajos Españoles, 1550-1650", Revista del Instituto de Historia del Derecho 'Ricardo Levene', XXVI (1980-1981), pp. 145-169.

9 Ernest H. Kossmann, Daan Roorda y Hugo de Schepper (eds.), Bureaucratie en bureaucratisering (Groningen: Tijdschrift voor Geschiedenis, XC/3-4, 1977), pp. 358-377.

10 Hugo de Schepper y Geoffrey Parker, "The Formation of Government Policy in the Catholic Netherlands under the Archdukes, 1596-1621", The English historical Review, XCI (1976), pp. 241-254; trad. castellana, "Los procesos de toma de decisión en el gobierno de los Países Bajos bajo 'los Archiduques', 1596-1621", en: España y los Países Bajos, 1559-1659. Diez Estudios, Geoffrey Parker (ed.), (Madrid: Rialp, 1986), pp. 224-244.
} 
pensiones y otras remuneraciones, así como de exenciones de impuestos y privilegios de "fuero" judicial. En cuanto a los orígenes geográficos de los consejeros, desde la Reconciliación de 1579 hasta la Tregua con las Provincias Unidas, los consejeros de ropa corta eran originarios principalmente de las provincias valonas y de Luxemburgo, mientras los demás consejeros tenían sus orígenes en la burguesía urbana de las provincias de Brabante, Flandes y Franco Condado ${ }^{11}$.

\section{Competencias de los Consejos de gobierno ${ }^{12}$}

Por la comisión oficial por la que se nombraba al Gobernador General como Lugarteniente del País Bajo y del Franco Condado (en las posesiones españolas, un virrey o viceré), se le delegaban teóricamente todas las prerrogativas del Soberano ${ }^{13}$. Sin embargo, esto se recortaría con las instrucciones secretas y particulares. Además, tenía el Gobernador General la obligación de dejarse guiar "por los asesoramientos y las reflexiones maduras" de los tres Consejos a su lado ${ }^{14}$. No obstante, la prerrogativa del jefe de gobierno - el Lugarteniente o el Soberano - de seguir la "sanior pars" al decidir, generalmente los Gobernadores Generales y los Archiduques se conformaron con los asesoramientos de la mayoría en los Consejos. En principio, todas las decisiones de gobierno salían a y en nombre del Soberano después de consulta de Consejo, sin más, por lo que en muchísimas ocasiones no sabemos qué Consejo se habría consultado o cual habría tomado la decisión.

Cada Consejo disponía de instrucciones propias desde octubre de 1531. A pesar de unas adecuaciones para el Consejo de Finanzas, las competencias

\footnotetext{
11 Hugo de Schepper, "Les Comtois au gouvernement des Pays-Bas et de la Franche-Comté, 1579-1609", en La Franche-Comté et les anciens Pays-Bas, XIIIe - XVIIIe siècles. Actes du Colloque international à Vesoul (Haute-Saône) et Tournai (Belgique), les 25, 26 et 27 octobre 2006, t. I: Aspects politiques, diplomatiques, religieux et artistiques, Laurence Delobette y Paul Delsalle (eds.), (Paris/Besançon: Presses Universitaires de Franche-Comté, 2009), pp. 173-194.

12 Werner Thomas y Luc Duerloo (eds.), Albert and Isabella, 1598-1621. Essays (Turnhout: Brepols, 1998), pp. 221-232.

13 Cartas de nombramiento para Farnesio, 1 de febrero de 1580 y 20 de diciembre de 1581, Algemeen Rijksarchief Brussels (ARB.), Audiëntie [en adelante ARB, Aud.], no 1222, ffo. 4849, y ffo. 61v-64), para Ernesto de Austria, 23 nov. 1593 (Ibid., ffo. 204-206), para Andrés de Austria, 12 de septiembre de 1598 (Ibid., no 1223, ffo. 163-164v), para Mansfeld, 6 de febrero de 1593, Archivo General de Simancas (AGS), Secretarías.Provinciales - Flandes [en adelante AGS, Secr.Prov.], leg. 2580, fo. 16), para Fuentes, 2 de mayo de 1595 (Ibid., fo. 43), para Alberto de Austria, 2 de agosto de 1595 (Ibid., fo. 41).

14 "Instruction et memoire à nostre [...] nepveur le prince de Parme", 1 feb. 1580 (ARB, Aud., $\mathrm{n}^{\circ}$ 1222, fo. 74-76v). También las instrucciones secretas para Farnesio, 20 de diciembre de 1581 (Ibid., ffo. 82-84v); para otros lugartenientes, 1593-1598 (Ibid., $\mathrm{n}^{0} 1222$, ffo. 227-233, passim; Ibid., $\mathrm{n}^{0}$ 1223, ffo. 165-172, AGS, Secr.Prov., leg. 2580, ffo. 23-30); instrucciones particulares para lugartenientes, 1581-1598 (ARB, Aud., nr. 1222, ffo. 78-81v, 171-174, 219225v; Ibid., nr. 1223, ffo. 173-179; AGS, Secr. Prov., leg. 2580, fo. 31); instrucciones secretas para Fuentes, 2 de mayo de 1595 (Biblioteca Nacional de España, Manuscritos, nr. 8695, ffo. 1-6); instrucciones particulares para Fuentes, 2 de mayo de 1595 (Ibid., ffo. 7-10v).
} 
de cada uno apenas habían sido adaptadas desde entonces, sino por la práctica. En dichas instrucciones se indicaba que, al entrar un Gobernador General en su oficio, el Soberano había mandado al Consejo de Estado asesorarle sobre las "grandes y principales materias y las cuestiones que se refieren al estado, la política general del gobierno, la paz, la seguridad y la defensa del país". El archiduque Alberto en 1595 fue el último Lugarteniente que Ilevaría consigo dichas instrucciones. ${ }^{15}$ Felipe IV, rey de las Españas, quien a partir de 1621 sucedía a los Archiduques como Soberano del País Bajo y de Borgoña, notó en 1632 que las instrucciones para el Consejo de Estado eran imprecisas. En efecto, en 1531, una docena de consejeros mayoritariamente noble, habían sido separados del Consejo Privado por Carlos V para actuar bajo la denominación de Consejo de Estado solamente como el natural asesor del Príncipe "u de su theniente general", sin tener ninguna jurisdicción ni competencias específicas. De este modo, en cualquier asunto en que el Consejo hubiera sido consultado, solo el Soberano o su Gobernador General podían decidir ${ }^{16}$. Por lo tanto, y a consecuencia de ello, el Consejo no tenía secretario propio, sino aquel del Soberano o del Teniente General.

De hecho y derecho, el Gobernador - a través de su valido -, decidía cuando y donde se debían someter asuntos al Consejo de Estado. De hecho, en los años sesenta del siglo XVI, muchas decisiones fueron tomadas en grupos pequeños de consejeros, sin la intervención de todos ellos, lo que produjo gran frustración de algunos consejeros de espada. Por lo tanto, el Gobernador podía pedir consejo cuándo quisiera, dependiendo de la importancia, de las circunstancias, de la oportunidad y de sus pareceres, en materias como el gobierno general, seguridad, estrategia militar, relaciones exteriores, de gobernación y relaciones con otros poderes. Por lo tanto, las actuaciones del Consejo de Estado fueron facultativas, y "Pour l'importance du faict" el Gobernador pudo concertar con el Consejo Privado en asuntos jurídicos. A resultas de su composición de nobles con raíces regionales, los Lugartenientes y los Archiduques consultaron también al Consejo de Estado para juzgar junto con Finanzas a que los Estados aprobaran demandas de ayudas financieras. Lo que sí se procuró evitar, en la medida de lo posible, fue confiar al Consejo de Estado el gobierno en caso de larga ausencia o fallecimiento del Gobernador, rememorando el desgraciado desenlace tras la muerte de Requesens en 1576. En estas circunstancias excepcionales, formalmente solo pudo llevar a cabo los asuntos en trámite.

En contraste con el Consejo de Estado, el Consejo Secreto y el de Finanzas eran instituciones permanentes y tenían cada uno jurisdicciones específicas dentro de las cuales buscaron soluciones concretas y tomaron decisiones,

15 Cfr. Michel Baelde y René Vermeir, "Conseil d'Etat, 1531-1702, 1718-1787, 1790-17951794", en Les institutions du gouvernement central des Pays-Bas Habsbourgeois, 1482-1795, Erik Aerts et al. (eds.), (Bruselas: Algemeen Rijksarchief Brussel, 1994), pp. 257-274.

${ }^{16}$ Cf. Santiago Fernández Conti, Los Consejos de Estado y Guerra de la Monarquía Hispana en tiempos de Felipe II, 1548-1598 (Valladolid: Junta de Castilla y León, 1998), pp. 238-240. 
encargándose de poner en marcha la ejecución de las mismas. Estando los elementos privados y públicos de la soberanía siempre muy vinculados entre sí, no obstante, se podría decir que el Consejo Privado trataba los asuntos públicos mientras el Consejo de Finanzas manejaba los intereses materiales. Sin embargo, los dominios de la Corona iban perdiendo sus aspectos particulares, pues sus rendimientos servían igualmente para financiar la administración pública.

Siendo la soberanía indivisible -sin separación de poderes-, las competencias del Consejo Privado se desarrollaron en los terrenos de "gracia", "justicia" y "policía", las cuales formaban los medios de poder de la soberanía del monarca"17. La "policía" cubría, entre otras cuestiones, la competencia legislativa, pero, a falta de tradición de legislación general, las leyes del Soberano cubrían, aunque bastante limitados, terrenos de la sociedad: el derecho político y administrativo, el derecho penal (entre otras cosas contra la herejía), el orden público, el derecho procesal, las tarifas monetarias, el comercio y el mantenimiento de diques, puentes y caminos. Las más de las veces, las iniciativas para edictos no emanaban del propio Soberano. En realidad, el Consejo Privado preparaba la voluntad legislativa del Príncipe, la tradujo en textos jurídicos y la promulgó como edicto, ordenanza o placart. Por lo tanto, el Consejo tenía casi el monopolio a la hora de proyectar y redactar leyes generales sucesivamente en nombre de Felipe II y de los Archiduques, eventualmente después del asesoramiento de los Consejos de Estado y/o de Finanzas y después de un proceso extenso de consulta de los Consejos Provinciales y las autoridades regionales y locales, incluidos grupos y comunidades interesadas. La mayoría de las leyes eran circunstanciales o reparativas ${ }^{18}$.

En el proceso de toma de decisiones legislativas, las intervenciones del Soberano fueron excepcionales. Por ejemplo, en julio de 1570, y después de casi cuarenta años de preparaciones en el seno del Consejo Secreto, se habían promulgado las importantísimas ordenanzas de derecho penal, tanto material como formal ${ }^{19}$. Solo durante los últimos meses antes de su publicación, y de manera concisa, Felipe II fue informado por el Gobernador General, el duque de Alba, sin pedir su consenso. En cambio, con respecto a la introducción de las alcabalas en noviembre 1568, Alba había enviado a Felipe II un proyecto concreto de ordenanzas para obtener la aprobación del

17 Hugo de Schepper, 'Conseil Privé, 1504-1794', en Les institutions, Aerts et al. (eds.), pp. 287-317.

18 Id., 'Une législation de circonstance aux Pays-Bas sous le gouvernement personnel d'Alexandre Farnèse, 1579-1589', en Légiférer, gouverner et juger. Mélanges d'histoire du droit et des institutions (IXe-XXIe siècle) offerts à Jean-Marie Cauchies offerts à l'occasion de ses 65 ans, Éric Bousmar, Philippe Desmette y Nicolas Simon (eds.), (Bruselas: Presses de I'Universitè Saint Louis, 2016), pp. 281-297.

19 Jean-Marie Cauchies, "La loi dans les Pays-Bas, XVIe-XVII ${ }^{e}$ siècles: gouvernance et administration", en Gouvernance et administration dans les provinces belgiques, XVI ${ }^{e}-X V I I I^{e}$ siècles. Ouvrage en hommage au Professeur Claude Bruneel, Claude de Moreau de Gerbehaye, Sébastien Dubois y Jean-Marie Yante (eds.), (Bruselas: Archives et bibliothèques de Belgique, 2013), pp. 59-79. 
Soberano. Pese a ello, y al tardar mucho tiempo la respuesta, el duque las publicó por iniciativa propia. En otra ocasión, en 1579, los Estados Generales del Franco Condado pidieron una reforma de la justicia, haciendo sugerencias. Concertando con el Parlamento de Dôle, el Consejo Privado compuso un borrador de códigos de reforma para Borgoña con nuevas disposiciones, sobre todo en derecho procesal, y en septiembre de 1583 fue enviado a Madrid por orden expresa de Felipe II. Después de unos pocos cambios menores, quedaron las minutas en la mesa del monarca durante más de dos años antes de firmarlas el 1 de febrero 1586, retornando entonces a Bruselas para la transcripción "en forma". Finalmente, se promulgaron en abril por el Parlamento borgoñón. ${ }^{20}$ Generalmente, por tanto, las minutas originales de los edictos eran firmadas solo por el Gobernador General.

Al someterse las relaciones particulares entre los súbditos todavía a múltiples costumbres locales, era el derecho consuetudinario mayoritariamente no escrito - la fuente primaria jurídica. Por la forma humanística de pensar de la ancha capa superior cultivada de la población, y por las necesidades económicas en las provincias económicamente más desarrolladas, la preferencia por un derecho racional intrínsecamente escrito con validez general se incrementó. Por lo tanto, y durante decenios, el Consejo Secreto procuró buscar una mayor unidad jurídica, dirigiendo un proceso de homologación del derecho consuetudinario a base de codificaciones de cientos de costumbres locales ${ }^{21}$. Así, en 1611 la preeminencia del derecho consuetudinario se rompió en favor del derecho escrito mediante la promulgación del "Edicto Perpetuo". Desde 1592, este monumento legislativo había sido preparado bajo la dirección del Consejo Privado, y en el mismo se contienen artículos sobre contratos, patrimonios familiares, testamentos notariales, medios probatorios (preferencia de documentos escritos a la deposición testimoniar), hipotecas y plazo prescriptivo. La publicación de esta primera gran tentativa para unificar el derecho civil fue un paso importante, aumentando la seguridad jurídica para los justiciables. Fue la verdadera ruptura del poder legislativo del Soberano en el terreno del derecho privado. Además, volvió a revalidar artículos del código penal de Alba, suprimido en la época revolucionaria por la Pacificación de Gante; supresión ratificada por Don Juan de Austria22.

La defensa activa de la autoridad y de los intereses del Soberano se enlazaba con la competencia legislativa. A través de la red de fiscales

${ }^{20}$ Apostillas del 8 marzo 1581 sobre resoluciones de los Estados Generales de Borgoña, [1579] (AGS., Secr. Prov., leg. 2568, fo. 52); borrador de ordenanza, s.f. [1583] (Ibid., leg. 2567, s.f.); ordenanza para Borgoña, 1 de febrero de 1586 (Ibid., leg. 2567, s.f.).

21 John Gilissen, "Les phases de la codification et de I'homologation des coutumes dans les XVII Provinces des Pays-Bas", Tijdschrift voor rechtsgeschiedenis, XVIII, (1950), pp. 36-67, 239-290.

22 Georges Martyn, Het Eeuwig Edict van 12 juli 161, en Rijksarchief in de provinciën. Studia, LXXXI (Bruselas: Algemeen Rijksarchief, 2000) 
provinciales y locales bajo la dirección de su propio fiscal, controlaba el Consejo Privado, el mantenimiento de la legislación y del orden público, buscando soluciones y fundamentos jurídicos en caso de infracciones y aberraciones. Informes sobre la mala aplicación de ordenanzas y placartes, así como sobre perturbaciones sistemáticas del orden público, provocaban persecuciones de infractores o cambios legislativos. Por supuesto, no todos los asuntos eclesiásticos escapaban al control del monarca. Así, el Consejo Secreto era la fuerza motriz para ejercer el ius nominandi en la mayoría de beneficios y altas dignidades de la iglesia y para ocupar y ampliar los iura circa sacra. Todas las decisiones eclesiásticas se sometieron obligatoriamente al placet del príncipe, es decir del Consejo Privado, antes de promulgarlas; así se las integraron en el derecho público del país. En el marco del apoyo a la reforma católica, estaba colocándose la enseñanza desde las escuelas parroquiales hasta de las universidades bajo la vigilancia del gobierno, de hecho, el Consejo Privado.

Al ser la justicia el alma y el núcleo de la causa pública, se la controló y se la organizó a través del Consejo Privado. Desde allí, se nombraba a los consejeros inamovibles del Gran Consejo, tribunal superior de apelación en Malinas, y en los demás Consejos de Justicia (tribunales de apelación por provincia), con excepción de los presidentes a los cuales nombró el Soberano mismo a propuesta del Consejo. En febrero de 1580 se ordenó a los consejeros fieles de Güeldres abandonar la ciudad insurgente de Arnhem para establecerse como tribunal provincial de Güeldres Superior en Ruremonde, del que más tarde se amplió la jurisdicción territorial hasta el exclave de Lingen y otras zonas de Overijssel reconquistadas bajo los Archiduques. Estimulaba el Consejo Privado la fusión de los antiguos tribunales feudales con los Consejos de Justicia modernos del Príncipe, aunque, en las provincias más feudalizadas como Hainaut y Luxemburgo, sin mucho éxito.

En todos los Consejos de Justicia, el Consejo Secreto intentó separar la fiscalía de los demás consejeros, con el fin de evitar que fuera juez y parte demandante en pleitos penales. Sin embargo, resulta claro que no había justicia independiente, ya que todos los Consejos, incluido el Gran Consejo, consultaban en numerosas ocasiones con el Consejo Privado antes de sentenciar. Además, el Consejo Secreto intervino en la jurisdicción de los tribunales consuetudinarios por el ejercicio del derecho monárquico de gracia, tanto en lo penal como en lo civil. A petición de múltiples justiciables era una manera exitosa de gerencia de conflictos. Al considerar el procedimiento de la gracia las circunstancias atenuantes de causas criminales (como un accidente o la legítima defensa), la otorgación de perdón era más eficaz que la justicia represiva de delincuentes ante los alcaldes y concejales locales y regionales. Sobre todo, demostró el ejercicio de la gracia el poder de la preeminencia del Soberano sobre la medieval justicia consuetudinaria. En el marco del derecho de gracia, el Consejo Privado otorgó además numerosas 
dispensas y permisos pasándose del derecho común, los cuales, como defensor de la soberanía principesca, hubiera tenido que impugnar ${ }^{23}$.

Por supuesto, era un pequeño paso para que el propio Consejo Privado administrara él mismo la justicia contenciosa, aunque sus instrucciones no se lo autorizaban, excepto en "causas extraordinarias". Pero, con el fin de evitar pleitos largos y casos de apelación ante varias instancias judiciales, y al buscar seguridad jurídica, personas físicas y jurídicas elevaron peticiones al Consejo Secreto, estimulando su papel de administrador de justicia. Hasta la evocación de pleitos, las más de las veces las demandas de justiciables se introdujeron ante el Consejo. Sin el interés de los litigantes, probablemente la justicia moderna del Soberano se hubiese limitado a materias reservadas ("casus reservati") y a una justicia privilegiada. En vigor de la justicia emanada del Soberano, el Consejo Secreto no careció de fundamentos jurídicos para renunciar al conocimiento de cualquier pleito, más que nada porque los litigantes quisieron buscar derecho lo más cerca del poder, el Príncipe. No sólo juzgaba en primera y última instancia de acciones personales, sino también de acciones posesorias y petitorias, hasta incluso entre dignatarios e instituciones eclesiásticas. Además, en casos de defecto de forma, el Consejo Privado fue solicitado para revisiones de sentencias que no permitían más apelación ni otros recursos judiciales. En ciertos aspectos, el Consejo Privado era la última instancia judicial del país, pues completaba la justicia superior ante el Gran Consejo.

Como custodio y defensor de los intereses y derechos del Soberano, igualmente formuló el Consejo juicios a denuncia de su fiscal en pleitos de delito de Lesa Majestad, falsificaciones monetarias, comercio con los enemigos sin permiso, ejecución de decisiones eclesiásticas sin placet, deudas al dominio de la Corona, fraudes u otras malversaciones en la gerencia de los dominios y finanzas,... Finalmente, funcionó como tribunal administrativo en conflictos de competencia entre los Consejos, entre los Consejos de Justicia y las Cámaras de Cuentas y entre otras jurisdicciones inferiores. Interesante es el procedimiento judicial por el cual personas tanto físicas como jurídicas pudieron oponerse a actos de la autoridad pública, consideradas ilícitas. No fue considerado como una actio contra legem, sino como una appellatio extraordinaria, por la cual no se citó a la autoridad del Soberano sino a los beneficiarios que habían pedido el acto. El derecho de la justicia y el de la gracia concedían al Soberano un volumen de poder que le procuró la posibilidad de tener la palabra final y de manifestar su voz preponderante en detrimento de las instituciones consuetudinarias. Sin embargo, solo un decenio después de la Reconciliación valona, la justicia ante los Consejos superiores del Soberano pudo iniciarse otra vez. De todos

${ }^{23}$ Hugo de Schepper, "Privileg und Gratia in den Burgundisch-Habsburgischen Niederlanden, 1400-1621. Eine historisch-theoretische Betrachtung", en Das Privileg im Europäischen Vergleich, II, B. Dölemeyer y H. Monhnhaupt (eds.), (Frankfurt am Main: Veröffentlichungen des Max-Planck-Instituts für europäische Rechtsgeschichte. Sonderhefte: Studien zur Europäischen Rechtsgeschichte, núm. 125, 1999), pp. 225-252. 
modos, debido a la pérdida de Holanda y Zelanda, provincias donde encontramos numerosos litigios, no se pudo conseguir el mismo nivel de poder que antes de los disturbios.

Apoyándose sobre una extensa red jerárquica de recaudadores y sobre cuatro Cámaras de Cuentas -entre 1585 y 1609 estaban en Lille, Ruremonde, Bruselas y Dôle (Borgoña)-, el Consejo de Finanzas gestionaba y controlaba la economía 24 ; entonces solo en el sentido de los dominios e ingresos del Soberano ("oikos", a diferenciar por tanto del "comercio"). La administración de la "economía" se desarrollaba siempre según el modelo borgoñón, que a su vez se había basado en gran parte en el modelo francés.

Los ingresos ordinarios se fundaron durante mucho tiempo sobre el patrimonio personal del Príncipe. Gran parte estaba constituida por la reducción a dinero de productos naturales procedentes de agricultura, ganadería, silvicultura y minería. Además, provenía de la recaudación de viejas prestaciones señoriales y "regalías", aunque el arriendo de tierras y de derechos descendió tras el inicio de la guerra civil, pues los candidatos arrendatarios se abstuvieron de responder a los convocantes por falta de confianza en el rendimiento.

Recaudadores particulares sacaron de los ingresos, sus propios gastos de administración y los gastos locales, así como el pago de las rentas sobre el patrimonio, costes de construcciones y de salarios. Solo después de la substracción de estos costes, los saldos eran remitidos a un recaudador superior quien los centralizaba por provincia (lantrentmeester, receveur general). Por razón de oficio, pagaba los salarios del estatúder, de los consejeros de justicia y otros oficiales de la provincia en cuestión. La época en que los ingresos provenientes de los recursos privados de la Corona bastaban para pagar la pompa real, los entourages, los palacios, el gobierno y las guerras, así como el equipamiento general del país, hacía mucho tiempo que pertenecía al pasado. Con la venta de rentas y arriendo de partes del dominio a gran escala, se trató de mantener el nivel de los ingresos. El descenso de los ingresos del dominio y el ritmo creciente de los gastos, hacían necesario que se negociaran siempre más donativos provinciales (beden, aides) con las clases privilegiadas en los Estados Provinciales, los cuales representaban teóricamente a los súbditos. Los resultados de estas negociaciones evolucionaron finalmente de entradas extraordinarios a ingresos de carácter ordinario.

Los ingresos extraordinarios, mientras, consistían en ingresos

\footnotetext{
24 Herman Coppens y Michel Baelde, "Conseil des Finances, 1504-1794", en Les institutions, Aerts et al. (eds.), pp. 497-521. Cf. Hugo de Schepper, 'La organización de las 'Finanzas' públicas en los Países Bajos Reales, 1480-1700. Una reseña', Cuadernos de la Investigación Histórica, VIII (Madrid: 1984), pp. 7-34.
} 
provenientes de derechos de feudos (leenverhef, relief de fief), así como de aubaniteit (derechos sobre los extranjeros), herencias de bastardías y beneficios provenientes principalmente de la justicia. Otras entradas extraordinarias provenían del derecho de sellos $y$, sobre todo, de derechos de "licentes", o impuestos de guerra sobre el comercio, inicialmente con países enemigos y desde 1572, con las provincias separadas. Para cobrar los ingresos extraordinarios existían recaudadores especiales, los cuales depositaban sus saldos en la Tesorería Secreta (Heymelicken Tresor, Espargne). Sin embargo, no existía una delimitación precisa con la competencia del recaudador central de Finanzas. Originalmente dependía esta caja 'secreta' directamente del Soberano para que éste pudiese disponer de dinero líquido. Desde 1567, el duque de Alba había confiado al Tesorero Secreto también la recaudación de ingresos provenientes de los bienes confiscados a causa de la "rebelión".

El Consejo de Finanzas perseguía la unidad de gerencia de todas las finanzas del Soberano, asimismo referente a los envíos de asientos desde España destinados a los tercios y al equipamiento militar en los Países Bajos, aunque sin éxito, pues el ejército español trajo consigo a sus propios funcionarios de gestión (a partir de 1595, la "Junta de Hacienda"), de manera que el Consejo de Finanzas quedó fuera de la gestión de esos fondos. A pesar de su gran importancia, solo excepcionalmente se presentan fragmentos en la contabilidad del recaudador general de Finanzas bajo la rúbrica deniers venans des coffres du Roy. Después de la muerte de Farnesio, se abolió la Tesorería Secreta y se la integró en la recaudación general de Finanzas. Mientras, los saldos de las imposiciones de guerra sobre el comercio ya habían aumentado en importancia por la generalización y mejor organización del sistema. Su superávit alcanzó a veces importantes cimas en la totalidad de los ingresos netos.

En la contabilidad central, los ingresos provenientes del patrimonio del Soberano fueron bajando, hasta llegar a menos del 20\% a partir de 1601 . Su baja relativa debe adscribirse al traspaso del "Heymelicken Tresor" y sobre todo al ritmo de los donativos, que desde 1590 presentaron cada vez más una tendencia más pronunciada a ser solicitados de forma más regular por el gobierno. Antes de 1600, nunca se había obtenido una cifra tan alta como los 3.600.000 florines anuales que aprobaron los Estados Generales en noviembre de 1600 . Desde entonces, solo los subsidios o donativos extraordinarios conservaban un carácter ocasional. Solo mediante los subsidios, guardaban los Estados Provinciales la facultad de ejercer presión política sobre el gobierno. Aunque en repetidas oportunidades el Consejo de Estado estuvo políticamente implicado en las negociaciones de los donativos, estos se desarrollaban técnicamente bajo la dirección de Finanzas. 
En todo caso, los saldos de los donativos contabilizados entre $1601 \mathrm{y}$ 1621 , constituyen del $40 \%$ hasta el $60 \%$ de los ingresos del recaudador general. El recaudador provincial de los donativos y su compañero del dominio estaban, en principio, en igual posición frente a las arcas generales de Finanzas. De hecho, en algunas ocasiones, ambos oficios fueron ejercidos por la misma persona. Mientras la recaudación de donativos fue asunto del Príncipe, se efectuó mediante "pago directo", por ejemplo, tanto a las tropas que estaban de paso como a las acuarteladas en la provincia. Incluso las recaudaciones de tributos estaban cada vez más en manos de los funcionarios de los Estados.

Junto a su función gerente del patrimonio y finanzas del Príncipe, el Consejo de Finanzas detenía la gestión de los gastos del Soberano. Ninguna alienación del dominio ni disminución de los ingresos del Príncipe podía surtir efecto sin discusión y aprobación del Consejo de Finanzas. Por lo menos tres consejeros, entre ellos un jefe o el tesorero general y dos comisarios, debían dar consentimiento para cualquier desembolso firmando en persona; además, se necesitó una segunda lectura antes de tener eficacia legal. El Soberano o su Teniente General solo excepcionalmente soslayó al acuerdo del Consejo para hacer pagos y donaciones o efectuar cualquier alienación.

La gerencia general implicaba la organización y el nombramiento de las capas subalternas de los dominios y de las finanzas, y asimismo de los calculadores y auditores en las Cámaras de Cuentas. Por la separación de Holanda y Zelanda, la Cámara de La Haya fue integrada en 1587 con la de Güeldres, que había trasladado su sede de Arnhem insurgente a Ruremonde, ciudad reconquistada. Las demás Cámaras volvieron a sus residencias después de la Reconquista por las tropas reales.

Las competencias de Finanzas significaban también que el Consejo debía aconsejar e informar sobre la legislación que tenía o podía tener relación con la "economía". Los edictos monetarios que fijaba la ley, el peso y tas tarifas nominales de las monedas metálicas en relación con la moneda de cuenta, se establecieron por Finanzas de acuerdo con el Consejo Privado. De hecho, después de la Cesión de Flandes a los Archiduques, el Consejo de Finanzas comenzó a oficiar a la vez como una suerte de ministerio de comercio e industria. Anteriormente, administró un régimen legislativo que estaba más inspirado por motivos políticos y fiscales. En 1599, introdujeron el 'Nieuwe Nederlandsche gulden' (el nuevo florín de los Países Bajos) con misma la ley de antes, pero a costa del peso metálico. Nominalmente era a pari con el florín de cuenta.

A pesar de que finalmente eran responsables ante el Consejo de Finanzas, todos los contables tuvieron que presentar sus cuentas para audición (auditie) ante las Cámaras de Cuentas. Solo si las cuentas 
cuadraban hasta el último céntimo, eran cerradas provisionalmente por la Cámara competente en espera de la decisión de Finanzas. De este modo, litigios que provenían del control de las cuentas, déficits e infracciones de contabilidad fueron dirimidos por la Cámara de Cuentas. Después del primer control, seguía un segundo por el Consejo de Finanzas, ante el cuál los recaudadores podían interponer apelación, o incluso ante el Consejo Privado. Si un recaudador seguía siendo considerado en falta por un importe determinado, o si se trataba de mala administración hasta incluso de malversación, la Cámara de Cuentas correspondiente proponía a Finanzas proceder a la ejecución para reclamar la deuda en juicio. Eventualmente inició enjuiciamiento penal por un fiscal de un Consejo de Justicia, hasta incluso, según la importancia del caso, por el fiscal del Consejo Privado. Además, al gestionar excesos de fecha de caducidad, insolvencia y otros fallos de contables, Finanzas decidía "por sentencia y derecho". En julio de 1560, al haberse unido el fiscal con el Consejo de Finanzas contra un recaudador regional de Edingen (Hainaut), acusado de reincidencia de piezas probatorias falsificadas y de desfalco de dinero, el Consejo Privado condenó al recaudador a la horca ${ }^{25}$.

En el último capítulo de la segunda parte, me detengo largamente sobre varios modelos de toma de decisión en el gobierno. En primer lugar, se trata sobre el protocolo en los Consejos y el establecimiento de asesorías al Príncipe o a su Lugarteniente. La consulta escrita como procedimiento asesor que respondía a un decreto -como en las relaciones de las Juntas y del Consejo de Estado con el Soberano en España- no era usual. Desde su cultura castellana más burocratizada, los Archiduques prescribieron la consulta a finales de 1603, pero únicamente en el Consejo de Finanzas. En el gobierno de Flandes, la tradición consultativa permaneció esencialmente oral, hasta que Felipe IV en 1632 ordenó que el procedimiento a boca en lo sucesivo fuera una excepción.

En la mayoría de sus competencias, el Consejo Privado y el de Finanzas conocían procedimientos específicos de decisión, dependientes de la materia. Evidentemente, el proceso legislativo no se desarrolló de la misma manera que un pleito judicial. En cuanto a la política y la gobernación del interior, los Consejos formularon y tomaron decisiones solo después de intercambiar ideas con las capas provinciales y locales ${ }^{26}$. Es importante subrayarlo. Además, cada vez antes de registrar su adhesión y promulgar una ley, los Consejos de Justicia tuvieron la ocasión de someterla a prueba con los privilegios y costumbres de la provincia concerniente. Tenían el derecho de hacer todavía observaciones y proponer cambios, e incluso podían posponer

${ }^{25}$ Sentencia del Consejo Privado, 9 de julio 1560 (ARB, Geheime Raad. Registers, núm. 671, ffo. 143-144).

${ }^{26}$ Nicolas Simon, "Une culture d'État?", en Légiférer, gouverner et juger. Mélanges d'histoire du droit et des institutions (IXe-XXI e siècle) offerts à Jean-Marie Cauchies offerts à l'occasion de ses 65 ans, Éric Bousmar, Philippe Desmette y Nicolas Simon (eds.), (Bruselas: Presses de I'Universitè Saint Louis, 2016), pp. 303-304. 
la promulgación. Pero, solo excepcionalmente usaron del derecho, porque en principio ya habían sido consultados en la fase preparatoria.

El procedimiento más ordinario para presentar cualquiera materia a nivel gubernativo era la solicitud escrita e introducida por un procurador jurado por encargo de individuos, gremios de comerciantes y artesanos, ciudades, instituciones..., tanto personas físicas como jurídicas. Hasta el $80 \%$ de las leyes generales promulgadas se establecieron a demanda de súbditos, y aún las ordenanzas legislativas motu proprio, regularmente eran leyes disfrazadas a petición de parte ${ }^{27}$. Los litigios -tanto acciones de derecho real y de derecho personal como acciones "fiscales" y administrativas- se establecieron igualmente por medio de solicitudes, formulando entonces quejas en juicio. Los litigantes ante el Consejo Privado no eran solo personas privilegiadas, sino también $y$, sobre todo, burgueses de las provincias marítimas económicamente dinámicas de Flandes y Brabante. La administración de justicia en el Consejo Secreto y en Finanzas era prácticamente independiente, pues Soberanos y Lugartenientes no asistieron a los pleitos ni participaron en la toma de sentencia.

Para el control de la contabilidad de los recaudadores, estos tenían que entregar cada año sus registros de ingresos y gastos y los justificantes del ejercicio pasado, junto con una estimación de ingresos y gastos con respecto al año venidero en un "estado" (staet, estat). En base a estos "presupuestos", el Consejo de Finanzas tenía la posibilidad de redactar un "estado general" para el Soberano y de gestionar los desembolsos. Al menos, esto era la teoría. Probablemente el presupuesto general de 1557 había sido el último que salió del Consejo de Finanzas a la atención de Felipe II, y estaba fechado el 29 de septiembre, icuando ya habían pasado 3/4 del año económico!

Desde los disturbios de la segunda mitad del siglo XVI, las previsiones de los recaudadores subalternos llegaron sólo esporádicamente al nivel central; de hecho, la obligación cayó en desuso. En los años Ochenta y Noventa, el Consejo de Finanzas se esforzó para reanudar los presupuestos anuales, aunque con escasa fortuna. Así, el Consejo no fue capaz de redactar anualmente presupuestos globales, de manera que la política presupuestaria era completamente desordenada e incluso ilusoria. A falta de "estados" válidos, los registros de los recaudadores eran la única manera de tener a posteriori una idea aproximada, aunque confusa, sobre los ingresos del Soberano de los Países Bajos. Empero, en estos decenios de caos por la guerra civil, muchas veces la entrega anual de los registros de contabilidad se hizo hasta con años de retraso. Los retrasos regulares impedían aún más al Consejo seguir la situación financiera, y Finanzas solo

27 John Gilissen, "Essai statistique de la législation en Belgique de 1507 à 1791", Revue du Nord, XL, (1958), pp. 431-435. 
tenía una idea precaria sobre la contabilidad del Príncipe y sobre la disponibilidad de sus activos.

Entre las diversas maneras de hacer el pago de salarios del personal en todas las capas de la justicia y "economía" u otros desembolsos, la "descarga" (deschargie, lettres de descharge) era el modo más frecuente. Era un documento que cumplía el papel de comprobante del recaudador general de Finanzas de haber cobrado un importe $(X)$ de un determinado recaudador (B) a favor de una persona definida (C). Formalmente era un recibo, pero que a su vez ordenaba a un recaudador subalterno pagar una cantidad a una tercera persona a causa de determinadas prestaciones. El importe se inscribió en el registro del recaudador general, tanto en los activos como en los pasivos. A continuación, la persona (C) se presentaba con la descarga en el despacho del recaudador (B) para cobrar la suma (X) en efectivo. Cuando el recaudador (B) disponía de dinero contante, pagaba e inscribía el importe en su pasivo con la descarga como justificación de la transferencia al recaudador general. Esta y otras técnicas contables dificultan a los historiadores evaluaciones precisas del presupuesto estatal de la época.

El traspaso del importe de los donativos aprobados por los Estados Provinciales hacia la tesorería central era cada vez más ficticio. A petición motivada (saqueos de militares, inundaciones...), el gobierno concedía "moderaciones" temporales y "gracias" impositivas, con las cuales los importes en cuestión eran deducidos a causa de no ser recuperables. Al negociar los donativos, el Consejo de Finanzas tuvo que conceder explícitamente a los Estados Provinciales la previa deducción de los pagos directos de soldada a las tropas estacionadas en sus respectivos territorios. Por otra parte, el gobierno estipuló pagos anticipados (anticipaties, anticipations) y venta de rentas sobre donativos futuros, lo que disminuyó los superávits de los donativos en la recaudación central.

\section{Historia política de los Consejos de gobierno}

La primera parte y segunda parte de esta monografía investigan a largo plazo las estructuras y el modelo de personajes que sirvieron dentro de los tres Consejos de gobierno, lo que resulta un corte más o menos estático de las instituciones concernientes. La tercera parte, mientras, dibuja en la perspectiva cronológica una imagen dinámica; o sea las actuaciones y toma de posiciones de los Consejos respecto a la coyuntura política y sus 
participaciones en los principales procesos decisionales desde 1580 hasta $1609^{28}$.

Entre los temas importantes de política exterior gestionados por los Consejos, podemos encontrarnos con: las relaciones con los principados obispales de Lieja y de Colonia; los problemas diplomáticos con el emperador Rodolfo II a consecuencia de las repetidas violaciones hasta de la ocupación de territorios imperiales por las tropas reales; la posición neutral del Franco Condado y el estatuto internacional de Besançon y Cambrai; la liga hereditaria del Franco Condado con los cantones suizos; la intervención militar en Francia; y las relaciones diplomáticas con Francia e Inglaterra que ayudaban a los Holandeses. En el interior: la proscripción de Orange; casos de Lesa Majestad; la política monetaria; política de precios y salarios; la controversia entre Iglesia y Estado, política comercial, ... Después de la Reconciliación de las provincias valonas, la pacificación y la reintegración de las demás provincias rebeldes, sea por negociaciones sea por las armas (capitulaciones de las ciudades flamencas y brabanzonas y de las zonas orientales), era la preocupación del gobierno que dominaba todos los demás asuntos políticos.

En aplicación del Tratado de Arrás, los tercios al servicio español habían abandonado el país hacia el 20 de abril 1580, y por consiguiente Alejandro Farnesio tuvo que partir, dejando el gobierno en manos de su madre, Margarita de Parma ${ }^{29}$. Sin embargo, el rey quiso continuar con la presencia de Farnesio en el país, por lo menos en la capitanía general de las tropas; lo que también era conforme con los deseos de Margarita. Sin embargo, Farnesio no quiso dividir el poder, aunque fuera con su madre y un par de días antes de la fecha planificada para su marcha, el príncipe de Parma informó oficialmente al Consejo de Estado de altercados vehementes con su madre. Por miedo a una catástrofe militar, el Consejo insistió en que Farnesio pospusiera provisionalmente su salida, y durante más de un año quedaron madre e hijo sin alcanzar un acuerdo y sin decisión del rey. Finalmente, el 2 de diciembre 1581, dos años después de su decisión de enviar a Margarita, Felipe II hizo redactar la carta de nombramiento y las instrucciones que confiaron los oficios integrales de Lugarteniente y Capitán General de los Países Bajos al príncipe de Parma. Hasta entonces, los progresos militares se habían limitado a unas ciudades aisladas en Flandes y a parte de las regiones orientales, las cuales optaron por el modelo valón.

La invasión del duque de Anjou, la ocupación de Cambrai y la difícil reconquista de Tournai (29 de noviembre de 1581), capital de la última

${ }^{28}$ Cf. Reginald de Schryver, "Politieke besluitvorming in de Zuidelijke Nederlanden tijdens het gouverneurschap van Maximiliaan Emanuel van Beieren, 1691-1711", en: Handelingen van het XXVIIe Vlaams Filologencongres, (1969), pp. 187-191.

29 A. Repetto Álvarez, "Acerca de un posible segundo gobierno de Margarita de Parma y el cardenal Granvela en los estados de Flandes", Hispania. Revista Española de Historia, XXXII (1972), pp. 379-475. 
provincia valona rebelde Tournésis, ilustraron la insuficiencia del ejercito valón desde de la salida de los tercios. Al abordar individualmente a los consejeros de espada de Estado y congraciarse con ellos, Farnesio pudo romper la resistencia contra el regreso de los soldados extranjeros. De este modo, a mediados de enero de 1582, el príncipe de Parma se atrevió a convocar a los diputados de los Estados valones en una reunión solemne general en Tournai, estando presentes los tres Consejos de gobierno. A la luz de la victoria de la ciudad, la única conquista importante desde la salida de las tropas extranjeras, la atmósfera era favorable para entender la demanda de Farnesio sobre el regreso el ejército español. Después de consultar a sus bases, volvieron los diputados con una respuesta positiva, pero bajo la condición de que el coste de soldada, entretenimiento y armamento fuera enteramente a cargo de la Hacienda española. Al pedir el Gobernador General al rey el retorno de los tercios, se dio un nuevo golpe negativo a la autoridad del Tratado de Reconciliación.

Solo en julio de 1583, la verdadera reconquista ofensiva contra las "Provincias Unidas" pudo arrancar con las capitulaciones de algunas pequeñas ciudades, que se potenciaría enormemente cuando en 1584 capitularon las grandes ciudades flamencas, Gante, Brujas y alrededores, ante la superioridad militar española. Las exigencias de estas ciudades como, por ejemplo, conceder sillas para protestantes en los Consejos, la legalización de los múltiples matrimonios "herejes" y la devolución de los bienes eclesiásticos confiscados por el régimen "rebelde" ... se rechazaron en el Consejo de Estado. Solo la libertad de conciencia pudo contar con la simpatía de la mayoría de los consejeros, pero el Gobernador General la rechazó como inaceptable por el rey Felipe. En lo sucesivo, Farnesio consultó únicamente con Richardot y un par de juristas del Consejo de Estado para discutir las condiciones de capitulación de las ciudades brabanzonas, en especial Bruselas como capital política y Amberes como capital económica y ciudad más protestante de los Países Bajos. De las concesiones a las provincias valonas no se encuentra casi nada en las capitulaciones que se impusieron a las ciudades reconquistadas por Parma. ${ }^{30}$

Ante la gran cantidad de protestantes que habitaban en las ciudades flamencas y brabanzonas (hasta el $30 \%$ ), el gobierno del príncipe de Parma se vio obligado a conceder temporadas limitadas de tolerancia religiosa; hasta dos años en el caso de Gante y cuatro en el caso de Amberes. Terminado el período, los habitantes tenían que abandonar sus posesiones u optar por una demanda de gracia sometiéndose oficialmente a la iglesia católica y a la soberanía del rey o por la pena de exilio u otras penas arbitrarias. Vendiendo sus propiedades, muchas decenas de miles de personas partían retirándose

\footnotetext{
30 Violet Soen, 'Reconquista and Reconciliation in the Dutch Revolt: the Campaign of GovernorGeneral Alexander Farnese, 1578-1592', Journal of Early Modern History, XVI (2012), pp. 1223.
} 
en la gran mayoría hacia "la patria liberada", que eran las ciudades holandesas y zelandesas. Después de la capitulación de Bruselas el 10 de marzo de 1585, los Consejos abandonaron su residencia provisional en Tournai y el 22 de junio siguiente regresaron en silencio sin tambor batiente al palacio de Coudenberg en Bruselas.

En el momento en que dichos Consejos entraban en Bruselas, prácticamente la mitad de los consejeros había sido rebelde en algún momento. Por ejemplo, de los seis miembros que quedaban en el Consejo de Estado, únicamente dos siempre habían sido fieles. Dudando de la sinceridad de su reconciliación, Farnesio no convocó más a dicho consejo desde noviembre de 1585 . Poco a poco, fue confiando en consejeros con un perfil más burócrata y en sus cortesanos italianos, en detrimento sobre todo del Consejo de Finanzas.

Una de sus preocupaciones, era que no pudo pedir donativos a los Estados de Brabante y Flandes, los cuales como miembros soberanos de las "Provincias Unidas" hasta 1587 tenían sus diputados en los Estados Generales de la Unión de Utrecht. Ante la acuciante necesidad de dinero para las tropas, el duque de Parma impuso derechos de "licentes" sobre el comercio con las provincias sublevadas y "contribuciones" sobre las poblaciones reconquistadas para liberarlas de alojamientos militares y rescatar motines. Las gerencias de estos ingresos se confiaron a sus cortesanos y familiares como fue el caso de su secretario particular Cósimo Masi-, solo responsables ante el propio príncipe de Parma. Incluso, se prohibió al Consejo de Finanzas ocuparse de estas recaudaciones y a las Cámaras de Cuentas de controlarlas, y el sello se le quitó al Consejo para concedérselo a un familiar de Parma.

Rumores sobre irregularidades contables y malversaciones, junto con la obstinación del duque contra la nueva orientación intervencionista de Felipe II en Francia, llevaron a la desgracia real del parmesano en 1592. Apoyado por los Estados y por los Consejos de gobierno, los cuales querían una política independiente, el duque de Parma no quiso perder las reconquistas recientes en un momento en que estaba a punto de atacar las últimas regiones insurgentes, y prefirió la continuación de la reconquista completa del país.

Falta de dinero, motines militares y la intervención de los tercios en Francia dieron ocasión a Mauricio de Nassau de organizar un ejército en toda regla y de recuperar el Norte de las provincias de Flandes y Brabante y todas las regiones más allá del Rin antes de 1598. Estos hechos daban la razón al duque de Parma, una razón que seguramente hubiera querido no tener, pues no era posible intervenir en Francia y a la vez continuar la guerra contra los rebeldes.

La guerra civil no se desarrolló únicamente en el campo de batalla, sino que también se había intentado batir a las regiones sublevadas con medidas monetarias y comerciales, elaboradas por el Consejo Privado en colaboración 
con el de Finanzas ${ }^{31}$. Igualmente, y a pesar de la escasez de cereales a causa de la destrucción en la guerra de la tierra agraria y de la dependencia de cereales bálticos a través de Ámsterdam, se prohibieron las relaciones comerciales con las provincias rebeldes y sus aliados. La prohibición de Requesens contra Holanda y Zelanda fue extendida a todas las provincias de la Unión de Utrecht. Al manifestarse la aplicación del embargo, quedó claro que era prácticamente imposible llevarlo a cabo debido al enorme volumen de contrabando, y el gobierno decidió fiscalizarlo publicando una ordenanza el 30 de noviembre 1586 con un listado de cerca de 300 productos, comestibles y materias primas que debían someterse a impuestos para la importación o exportación (licentes). Bienes estratégicos útiles a las tropas enemigas o a la economía "rebelde" no pudieron exportarse sino bajo licencias otorgadas por el Consejo de Finanzas, tasadas con altos impuestos. El embargo del comercio con las regiones insurrectas bajo el régimen de permisos e impuestos, quedó en vigor hasta 1598, adaptándose de vez en cuando los listados de productos ${ }^{32}$. Toda esta legislación se había establecido sin concertación con Felipe II, pues la fiscalización del comercio rindió mucho para las finanzas del estado siempre menesterosas.

El 4 de agosto 1590, Farnesio había abandonado Bruselas por orden explícita del rey para intervenir en Francia con tropas, dejando al conde de Mansfeld como Gobernador interino. La primera medida que tomó el conde, fue convocar directamente al Consejo de Estado, con la idea de restablecer a los Consejos en sus respectivas jurisdicciones. Al retornar a Bruselas, Parma canceló automáticamente las medidas tomadas por Mansfeld, lo que no redundó en beneficio de las relaciones entre ellos. Éstas empeorarían aún más durante la siguiente interinidad de Mansfeld, tras la nueva orden de Felipe II al duque de Parma de intervenir en Francia. Mansfeld, que quedaba sin poderes militares, pero, con el apoyo del Consejo de Estado, rehusó enviar tropas auxiliares a Francia tras la demanda de Farnesio. Al morir el duque de Parma a finales de 1592, el conde de Mansfeld pudo continuar su interinidad hasta la llegada de un nuevo Gobernador General, teniendo como prioridad durante dicho periodo la restauración de las competencias institucionales.

Para la intervención militar en Francia, Felipe II había enviado a Bruselas una serie de oficiales españoles. Empero, estos personajes se ocuparon también de asuntos de orden interno de los Países Bajos, lo que dio ocasión a múltiples fricciones con los Consejos bajo el archiduque Ernesto de Austria y el conde de Fuentes, que sucedieron rápidamente a Mansfeld como Gobernadores Generales. Al lado de los Consejos de Estado y de Finanzas

31 Placartes monetarios, 24 de enero de 1581 (ARB, Aud., $\mathrm{n}^{\circ} 1171$, ffo $58 \mathrm{v}-60$ ), 1 de marzo de 1583 (Ibid., $\mathrm{n}^{\circ} 1146, \mathrm{s.f}^{\circ}$ ), 15 de enero de 1584 (Idem, n 1104, s.f.), 20 de septiembre de 1581 (Koninklijke Bibliotheek Brusselas (KB.), Kostbare Werken, n० LP 2079 A), 4 de octubre de 1585 (Ibid., n LP II 6994 A 18); Idem, 23 de diciembre de 1588 (Idem, n LP 2387 A), 30 de abril de 1590 (Placcaeten ende ordonnantiën van Brabandt, t. 2, pp. 513-519).

32 Ordenanza, 30 de noviembre de 1586 (ARB, Aud., no 1146, s.f.); "Nieuwe liste Vande Rechten van Licenten", 20 de marzo de 1592 (KB, Kostbare Werken, nos LP 2486 A y LP 2487 A). 
estaba la presencia castellana desarrollándose como un "poder paralelo" 33 . La llegada del siguiente Lugarteniente, el archiduque Alberto de Austria en febrero de 1596 con una corte de 230 individuos nombrados personalmente por el rey, tenía que reforzar aún más la castellanización de Flandes y su integración en la Monarquía Hispana. De hecho, la Cesión de los Países Bajos a la infanta Isabel en 1598 no cambió mucho la situación.

Cómo ejemplo baste la medida que Isabel Clara Eugenia tomó en 9 de febrero de 1599 prohibiendo por ley toda circulación de personas y bienes con las regiones sublevadas tras ser presionada por Felipe III, pese a la preferencia de los consejeros flamencos de continuar el tráfico comercial con las provincias sublevadas y sus aliados bajo el sistema de imposiciones tarifadas sobre mercancías "permitidas" y de pasaportes mediante pago de altos importes para mercancías "prohibidas" a causa de la dependencia de cereales bálticos y del provecho para el tesoro.

Ésta y otras intervenciones ilustran como Felipe III interpretaba la independencia de los Archiduques. ${ }^{34}$ Además, el rey se representaba en Bruselas por el embajador Baltasar de Zúñiga y Fonseca, quien tenía el derecho garantizado de acceso ilimitado a los Archiduques sin pedir permiso. Junto con el secretario de Estado y Guerra Juan de Manciçidor y el maestre de campo Ambrogio Spínola, ambos nombrados por el rey -formalmente también por los Archiduques-, el embajador era el canal de confianza de Felipe III y de su Consejo de Estado para armonizar la política archiducal y los intereses de la Monarquía. La cantidad de agentes españoles, aproximadamente un $40 \%$ del personal total en la Corte en posiciones clave, nos indica que bajo Alberto e Isabel tenían una influencia como nunca antes. ${ }^{35}$ Debido, sobre todo, a la dependencia de la Hacienda y de los tercios españoles y por la fuerte presencia de diplomáticos de España, la soberanía de los Archiduques era un "asunto simulado", tal y como lo había formulado Jean Richardot.

La injerencia de estas "personas de experiençia y pratica en las cossas de la guerra y hazienda" repercutió notablemente, cómo es lógico, en las actividades del gobierno flamenco. En muchas ocasiones, los Archiduques se encontraron entre la espada y la pared, pues la política de guerra y paz, al quedar en el terreno exclusivo del rey de las Españas, se escapó a los consejos flamencos a pesar de los esfuerzos de los Archiduques

\footnotetext{
33 La expresión está tomada de la publicación de mi alumno y colega José Javier Ruiz Ibáñez, "Monarquía, guerra e individuo en la década de 1590: El socorro de Lier de 1595", Hispania. Revista española de historia, LVII/1 (1997), pp. 37-62 (espec. 42).

34 Alicia Esteban Estríngana, "Los Estados de Flandes. Reversión de las provincias leales, 15981623", en La Monarquía de Felipe III. Los Reinos, José Martínez Millán y Maria Antonietta Visceglia (eds.), (Madrid: Fundación Mapfre, 2008), IV, pp. 595-652.

35 Werner Thomas, "The "Spanish Faction" at the court of the archdukes Albert and Isabella", en $A$ Constellation of Courts, Vermeir et al. , pp. 167- 221; Dries Raeymaekers, One Foot in the Palace. The Habsburg Court of Brussels and the Politics of Access in the Reign of Albert and Isabella, 1598-1621 (Leuven: 2013).
} 
para llevar a cabo una política independiente. Así, después de 1600, se opusieron los agentes españoles a la convocatoria de los Estados Generales para evitar presiones sobre el proceso de pacificación con las provincias sublevadas. De este modo, consiguieron la integración de las tropas en el ejército de la Monarquía.

Igualmente, el 27 de febrero 1603, Felipe III firmó un edicto introduciendo una nueva política económica para la Monarquía Hispana, con la inclusión del País Bajo archiducal. Después de concertar con el "poder paralelo", los Archiduques publicaron el 5 de abril de 1603 una ordenanza de ley para hacer posible la aplicación del edicto español, al cual podemos considerar como el primer intento mercantilista. Para controlar la procedencia de las mercancías y el fraude en las licencias, se nombró a un español como un proveedor central de comercio, el cual extendía certificados de procedencia y llevaba un registro del comercio ${ }^{36}$.

Mientras, al continuar la política confesionalista de su padre, Felipe III ponía trabas a la pacificación de los Países Bajos, ya que se indicaba expresamente que con protestantes y rebeldes no se negociaba. Así, se cortó el paso a los contactos bilaterales entre el gobierno de los Archiduques y el gobierno rebelde en La Haya sin intervención ibérica, una exigencia de los holandeses en la cual el Consejo de Estado en Bruselas hubiera querido acceder. Así es que, cuando el Consejo de Estado en Bruselas fue consultado por los Archiduques sobre negociaciones para restaurar su soberanía en las provincias separadas, siempre tenía que tener en cuenta a Felipe III como rey de las Españas y à su gobierno. Por ejemplo, la libertad de conciencia para las provincias insurrectas conditio sine qua non- parecía buena idea a los consejos flamencos, pero desde 1605 no se los implicó más en el asunto del proceso de pacificación y no se llevó a cabo su propuesta.

Por lo demás, Felipe III y su "poder paralelo" en Bruselas respetaron generalmente la autonomía interna de los Países Bajos archiducales. Sin embargo, debemos considerar de todos modos que, bajo los Archiduques, Flandes se incorporó como satélite en el ambiente hispano. En 1609 los representantes de Felipe III en su calidad de rey de las Españas firmaron la Tregua de Doce Años con la República de la Provincias Unidas. El valido archiducal, Jean Richardot, formó parte de la delegación española. De este modo, un tratado de derecho internacional concluía temporalmente con la guerra interna de los Países Bajos, que se reanudaría doce años más tarde entre Felipe IV y la República Holandesa, la cual siguió aspirando a la restauración de la Unión de Utrecht con las provincias de Brabante y Flandes.

36 Miguel Ángel Echevarría Bacigalupe, "Un notable episodio en la guerra hispano-holandesa: el decreto Gauna, 1603", Hispania. Revista española de historia, CLXII (1986), pp. 57-97. 


\section{Agradecimientos}

Finalmente, tengo el placer y el deber de agradecer muchísimo a todos los que me han hecho el honor de estar aquí en Nimega conmigo en el campo que mi predecesor Poelhekke, el historiador de Federico Enrique de Nassau y de la Paz de Münster, siempre llamó "la Mookerheide", donde en 1574 ante el ejército español los rebeldes flamencos sufrieron una gran derrota. Aprecio con emoción sus condolencias y simpatía con ocasión del fallecimiento de mi mujer, la semana pasada. Agradezco además su paciencia, tolerando los cambios del programa por imperativos de mi salud actual.

Más de veinte sabios consagrados y sobre todo jóvenes se han esforzado por participar en este Congreso con una conferencia de historia institucional de la época española. Felicito a todos los conferenciantes sin ninguna excepción por sus nuevas aportaciones interesantes a uno de mis terrenos preferidos de investigación desde hace más de medio siglo. Compruebo que la historia institucional tiene un futuro. La innovación que yo quizás he podido aportar en la historiografía de las instituciones, la debo sin embargo a mi estancia de nueve años profesionalmente felices en la Facultad de Derecho de la Universidad de Ámsterdam, dirigiendo a un equipo de investigación de juristas, politólogos e historiadores en relación con la alta justicia. Por supuesto, la debo también a mis alumnos, tanto a mis casi veinte promoti como a los demás estudiantes que he tenido durante mi docencia en la universidad.

Finalmente, quiero manifestar mi profunda gratitud a los organizadores de este congreso, el noveno en la serie Hispano-Holandés-Belga, los doctores Gijs Versteegen, de la Universidad Rey Juan Carlos, y Pierre-François Pirlet, de I'Université de Liège; y en especial a los directores, los doctores José Eloy Hortal Muñoz y Dries Raeymakers. Digo explícitamente Dries, pues simboliza el legado borgoñón que une el Franco Condado, España y las Diez y Siete Provincias del País Bajo. También en la Francia centralista desde hace algunos años, el Franco Condado y los departamentos del Norte de Francia van dándose cuenta de estas raíces comunes. Espero que la Universidad de Nimega se dé cuenta de esta riqueza para reanimar el área de Historia Moderna bajo los estímulos del profesor recientemente premiado Dries Raeymakers. Dries, te deseo mucho éxito con esta empresa.

Nada más. iHasta el $X^{\circ}$ congreso de historiadores hispanistas! iHasta la próxima! 
Bibliografía:

Baelde y Vermeir 1994: Michel Baelde y René Vermeir, "Conseil d'Etat, 15311702, 1718-1787, 1790-1795-1794", en Les institutions du gouvernement central des Pays-Bas Habsbourgeois, 1482-1795, eds. Erik Aerts et al., (Bruselas: Algemeen Rijksarchief Brussel, 1994), pp. 257-274.

Cauchies 2013: Jean-Marie Cauchies, "La loi dans les Pays-Bas, XVI ${ }^{\mathrm{e}}-\mathrm{XVII}^{\mathrm{e}}$ siècles: gouvernance et administration", en Gouvernance et administration dans les provinces belgiques, XVI $-X V I I I^{e}$ siècles. Ouvrage en hommage au Professeur Claude Bruneel, eds. Claude de Moreau de Gerbehaye, Sébastien Dubois y Jean-Marie Yante, (Bruxelles: Archives et bibliothèques de Belgique, 2013), pp. 59-79.

Coppens y Baelde 1994: Herman Coppens y Michel Baelde, "Conseil des Finances, 1504-1794", en Les institutions du gouvernement central des PaysBas Habsbourgeois, 1482-1795, eds. Erik Aerts et al., (Bruxelles: Algemeen Rijksarchief Brussel, 1994), pp. 497-521.

De Schepper 1980-1981: Hugo de Schepper, "El nombramiento de altos magistrados y funcionarios para los Países Bajos Españoles, 1550-1650", Revista del Instituto de Historia del Derecho 'Ricardo Levene', XXVI, (19801981), pp. 145-169.

De Schepper 1984: Hugo de Schepper, "La organización de las 'Finanzas' públicas en los Países Bajos Reales, 1480-1700. Una reseña", Cuadernos de la Investigación Histórica, VIII, (Madrid: 1984), pp. 7-34.

De Schepper 1994: Hugo de Schepper, "Conseil Privé, 1504-1794", en Les institutions du gouvernement central des Pays-Bas Habsbourgeois, 14821795, eds. Erik Aerts et al., (Bruxelles: Algemeen Rijksarchief Brussels, 1994), pp. 287-317.

De Schepper 1999: Hugo de Schepper, "Privileg und Gratia in den Burgundish-Habsburgischen Niederlanden, 1400-1621. Eine historischtheoretische Betrachtung", en Das Privileg im Europäischem Vergleich, II, eds. B. Dölemeyer y $\mathrm{H}$. Mohnhaupt. Veröffentlichungen des Max-PlanckInstituts für europäische Rechtsgeschichte. Sonderhefte: Studien zur Europäischen Rechtsgeschichte, (Frankfurt: Klostermann, 1999), pp. 225252, no 125.

De Schepper 2009: Hugo de Schepper, "Les Comtois au gouvernement des Pays-Bas et de la Franche-Comté, 1579-1609", en La Franche-Comté et les anciens Pays-Bas, XIIIe - XVIIIe siècles. Actes du Colloque international à Vesoul (Haute-Saône) et Tournai (Belgique), les 25, 26 et 27 octobre 2006, t.I: Aspects politiques, diplomatiques, religieux et artistiques, eds. Laurence 
Delobette y Paul Delsalle, (París/Besançon: Presses Universitaires de Franche-Comté, 2009), pp. 173-194.

De Schepper 2016: Hugo de Schepper, "Une législation de circonstance aux Pays-Bas sous le gouvernement personnel d'Alexandre Farnèse, 1579-1589", en Légiférer, gouverner et juger, eds. Eric Bousmar et al., (Bruxelles: Université Saint-Louis, 2016), pp. 281-297.

De Schepper y Parker 1976: Hugo de Schepper y Geoffrey Parker, "The Formation of Government Policy in the Catholic Netherlands under the Archdukes, 1596-1621", en The English historical Review, XCI, (1976), pp. 241-254; trad. castellana, "Los procesos de toma de decisión en el gobierno de los Países Bajos bajo 'los Archiduques', 1596-1621", en España y los Países Bajos, 1559-1659. Diez Estudios, ed. Geoffrey Parker, (Madrid: Rialp, 1986), pp. 224-244.

De Schryver 1969: Reginald de Schryver, "Politieke besluitvorming in de Zuidelijke Nederlanden tijdens het gouverneurschap van Maximiliaan Emanuel van Beieren, 1691-1711", en Handelingen van het XXVIIe Vlaams Filologencongres, (1969), pp. 187-191.

Echevarría Bacigalupe 1986: Miguel Ángel Echevarría Bacigalupe, "Un notable episodio en la guerra hispano-holandesa: el decreto Gauna, 1603", Hispania. Revista española de historia, CLXII, (1986), pp. 57-97.

Esteban Estríngana 2004: Alicia Esteban Estríngana, "Las provincias de Flandes y la Monarquía de España. Instrumentos y fines de la política regia en el contexto de la restitución de soberanía de 1621", en La Monarquía de las Naciones. Patria, nación y naturaleza en la Monarquía de España, eds. Antonio Álvarez-Ossorio Alvariño y Bernardo José García García, (Madrid: Fundación Carlos de Amberes, 2004), pp. 215-245.

Esteban Estríngana 2008: Alicia Esteban Estríngana, "Los Estados de Flandes. Reversión de las provincias leales, 1598-1623", en La Monarquía de Felipe III. Los Reinos, dirs. José Martínez Millán y Maria Antonietta Visceglia, (Madrid: Fundación Mapfre, 2008), IV, pp. 595-652.

Esteban Estríngana 2014: "Flemish elites under Philip III's patronage, 15981621: household, court and territory in the Spanish Habsburg Monarchy", en A Constellations of Courts. The Courts and Households of Habsburg Europe, 1555-1665, dirs. René Vermeir, Dries Raeymaekers y José Eloy Hortal Muñoz, (Lovaina: Leuven University Press, 2014), pp. 123-166.

Esteban Estríngana 2015: Alicia Esteban Estríngana, "De capitanías generales y tesorerías militares: el control financiero y sus dilemas en tiempos de Alejandro Farnesio, siglo XVI", Estudis. Revista de Historia Moderna, XLI, 2015, pp. 9-42. 
Fernández Conti 1998: Santiago Fernández Conti, Los Consejos de Estado y Guerra de la Monarquía Hispana en tiempos de Felipe II, 1548-1598, (Valladolid: Junta de Castilla y León, 1998).

García García 2002: Bernardo José García García, "'Ganar los corazones y obligar los vecinos'. Estrategias de pacificación de los Países Bajos (1604 1610)" en España y las 17 Provincias de los Países Bajos. Una revisión historiográfica, siglos XVI-XVIII, eds. Ana Crespo Solana y Manuel Herrero Sánchez, (Córdoba: Universidad, 2002), I, pp. 137-166.

Gilissen 1950: John Gilissen, "Les phases de la codification et de I'homologation des coutumes dans les XVII Provinces des Pays-Bas", Tijdschrift voor rechtsgeschiedenis, XVIII, (1950), pp. 36-67, 239-290.

Gilissen 1958: John Gilissen, "Essai statistique de la législation en Belgique de 1507 à 1791", Revue du Nord, XL, (1958), pp. 431-435.

Kossmann et al. 1977: Ernest H. Kossmann, Daan Roorda y Hugo de Schepper (eds.), Bureaucratie en bureaucratisering, (Groningen: Tijdschrift voor Geschiedenis, 1977) XC/3-4, pp.358-377.

Martyn 2000: Georges Martyn, "Het Eeuwig Edict van 12 juli 1611" en Rijksarchief in de provinciën. Studia, LXXXI, (Bruselas: Algemeen Rijksarchief, 2000), 610p.

Mesa Gallego 2009: Eduardo de Mesa Gallego, La pacificación de Flandes. Spínola y las campañas de Frisia, 1604-1609, (Madrid: Ministerio de Defensa, 2009).

Raeymaekers 2013: Dries Raeymaekers, One Foot in the Palace. The Habsburg Court of Brussels and the Politics of Access in the Reign of Albert and Isabella, 1598-1621, (Lovaina: Leuven University Press, 2013).

Repetto Álvarez 1968: Adela Repetto Álvarez, "Felipe II y el hijo del Príncipe de Orange", en Boletin de la real Academia de la Historia, t. 162, (1968), pp. 63-95.

Repetto Álvarez 1972: Adela Repetto Álvarez, "Acerca de un posible segundo gobierno de Margarita de Parma y el cardenal Granvela en los estados de Flandes", en Hispania. Revista Española de Historia, XXXII, (1972), pp. 379475.

Ruíz Ibáñez 1997: José Javier Ruiz Ibáñez, "Monarquía, guerra e individuo en la década de 1590: El socorro de Lier de 1595", en Hispania. Revista española de historia, LVII/1, (1997), pp. 37-62.

Simon 2016: Nicolas Simon, "Une culture d'État?", en Légiférer, gouverner et juger. Mélanges $d^{\prime \prime h i s t o i r e ~ d u ~ d r o i t ~ e t ~ d e s ~ i n s t i t u t i o n s ~(I X e-X X I ~ s i e ̀ c l e) ~}$ offerts à Jean-Marie Cauchies offerts à I'occasion de ses 65 ans, eds. Éric 
Bousmar, Philippe Desmette y Nicolas Simon, (Bruselas: Presses de I'Universitè Saint Louis, 2016), pp. 299-312.

Soen 2012: Violet Soen, 'Reconquista and Reconciliation in the Dutch Revolt: the Campaign of Governor-General Alexander Farnese, 1578-1592', en Journal of Early Modern History, XVI, (2012), pp. 1-223.

Thomas y Duerloo 1998: Werner Thomas y Luc Duerloo (eds.), Albert and Isabella, 1598-1621. Essays, (Turnhout: Brepols, 1998).

Thomas 2014: Werner Thomas, "The "Spanish Faction" at the court of the archdukes Albert and Isabella", en A Constellations of Courts. The Courts and Households of Habsburg Europe, 1555-1665, dirs. René Vermeir, Dries Raeymaekers y José Eloy Hortal Muñoz, (Lovaina: Leuven University Press, 2014), pp. 167- 221.

VVAA 1964: Nationaal Biografisch Woordenboek (Bruselas: Belgische Academiën, 1964), 22 vols. 